Yaroslav Humnytskyy and Oksana Matsuska

\title{
STATICS AND KINETICS OF AMMONIUM NITROGEN SORPTION ON NATURAL ZEOLITE UNDER PERIODIC CONDITIONS
}

\author{
Lviv Polytechnic N ational University, 12 St. Bandera str., 79013 Lviv, Ukraine \\ kasanam@meta.ua
}

Received: J anuary 27, 2010 / Revised: J une 29, 2010 / Accepted: September 30, 2010

(C) Humnytskyy Y., Matsuska O., 2011

\begin{abstract}
Statics and kinetics of ammonium nitrogen absorption on natural zeolite were investigated experimentally under periodic conditions. A mathematical kinetics model was developed and a counterion diffusion coefficient was defined. The influence of phosphate compounds and protein on equilibrium and a rate of ammonium ion sorption was investigated.
\end{abstract}

Keywords: ammonium nitrogen, zeolite, equilibrium, mathematical model, sewage water.

\section{Introduction}

Intensive development of industry, agriculture, power industry, transport, public service is accompanied by usage of considerable volumes of water, with its quality to be in conformity with the standarts. Depending on the object of usage, the water quality indices are divided into certain categories according to harmfulness. Not only water consumers use water in compliance with the standards specified. The used (sewage) water before its discharge into natural water reservoirs should meet certain criteria concerning the concentration of chemical mineral and organic compounds, bacterial pollutants, hang-up substances [1]. Discharge of polluted sewage water into natural water reservoirs has caused the situation which shows that presently all surface water sources in Ukraine according to the content level of pollutants have approached the IV-V class of water quality, and therefore the mentioned sources are characterized as polluted and higly polluted [2, 3]. This leads to a catastrophic degradation of water reservoir ecological systems [4].

Agricultural cattle production complexes and meat and milk processing plants are industrial environmental polluters.

Processing of farm products requires usage of great quantity of water which after its industrial use is enriched with organic substances and also a number of biogenic elements, first of all nitrogen and phosphorus compounds [5].
The occurrence of these elements in water objects is limiting for water vegetation causing eutrophication. As a result of rapid growth of the vegetation, the oxygen dissolved in water is sharply reduced, the process of its selfcleaning is disturbed, that causes perishing of aerobic flora and fauna [6].

The nitrogen compounds, which are capable to accumulate in surface and ground waters and also in air, are especially dangerous for humans, animals and plants [7].

Concentration of the ammonium nitrogen in sewage water from meat processing plants ranges within 1.0 $3.2 \mathrm{mg} \cdot \mathrm{eq} / \mathrm{dm}^{3}$ and exceeds their maximum allowable concentration (MAC of $\mathrm{NH}_{4}^{+}<1.1 \mathrm{mg} \cdot \mathrm{eq} / \mathrm{dm}^{3}$ ) [12], therefore the sewage water before discharge from the plant requires cleaning. In order to decrease the load on water objects, especially to prevent the eutrophication of water reservoirs, in practice cleaning of the sewage water is done by coagulation, settling with the following filtration through the sand filters. However, after such cleaning, the sewage water contains a great quantity of the ammonium nitrogen which cannot be removed from water by the mentioned methods.

Harmful impurities may be removed from the sewage water by various methods [1]. Viewing the fact that great volumes of the sewage water are subject to cleaning, the most economically reasonable is usage of natural sorbents which after the cleaning process may be used as fertilizers for agricultural needs. This sorbent, apart from introduction of nutrition elements into the ground, improves its structure. Taking into consideration this fact, we used zeolite as a sorbent which main ingredient is clinoptilolite in a sodium form [8].

The object of the work was investigation of the statics and kinetics of the ammonium ion sorpion by zeolite in the range of low concentrations characteristic of the sewage water from meat processing plants and also the influence of the accompanying pollutans of the sewage water on the $\mathrm{NH}_{4}{ }^{+}$absorption processes. 


\section{Experimental}

\subsection{Statics of the Ammonium Ion Sorption}

To determine an adsorption capacity of the ammonium ions, each of the glass flasks was filled with $200 \mathrm{ml}$ of the ammonium nitrate solution, prepared in the distilled water, of various initial concentrations $\left(C_{\text {init }}=\right.$ $\left.=0.55-3.33 \mathrm{mg} \cdot \mathrm{eq} / \mathrm{dm}^{3}\right)$ and equal portions of clinoptilolite $(\sim 1 \mathrm{~g})$ were added. The concentration range corresponded to concentrations of the ammonium group in the real sewage water. The flasks were sealed hermetically and kept at $(293 \pm 0.5) \mathrm{K}$ for two days with periodical stirring. The sorbent was separated from the solution which was analyzed for the content of the ammonium ions using a photocolorimeter and the known technigue [9].

At the following stages, the zeolite adsorption capacity was investigated relatively to the ammonium ions at the presence of two or three polluting components in the solution simultaneously. Among these pollutants in the sewage water, there are present phosphates and proteins which concentration is also regulated. The model solution, in which there were present the ammonium nitrogen and phosphates, corresponded to the two-component system. The adsorption of the ammonium nitrogen on the clinoptilolite at the presence of the phosphates with the initial concentrations of the ammonium nitrogen $\left(\mathrm{C}_{\text {init }}=0.55\right.$ $\left.-3.33 \mathrm{mg} \cdot \mathrm{eq} / \mathrm{dm}^{3}\right)$ and the initial content of the phosphates $\left(C_{\text {init }}=0.03-0.2 \mathrm{mg} \cdot \mathrm{eq} / \mathrm{dm}^{3}\right)$ was performed with the periodic stirring of water solutions at $(293 \pm 0.5) \mathrm{K}$. The solution: adsorbent ratio was $200 \mathrm{ml}: 1 \mathrm{~g}$ of the clinoptilolite. The contact time was two days. The sorption of the ammonium ions from the three-component system, where albumin with the initial concentrations $\left(\mathrm{C}_{\text {init }}=0.013-\right.$ $0.13 \mathrm{mg} \cdot \mathrm{eq} / \mathrm{dm}^{3}$ ) was added as the third pollutant, was carried out under the same conditions as in previous investigations with the solution: adsorbent ratio of $100 \mathrm{ml}: 1 \mathrm{~g}$ of the clinoptilolite. The solutions were analyzed for the content of the ammonium ions by using the photocolorimeter and the technique [9].

\subsection{Kinetics of the Ammonium Ions Sorption on Zeolite}

To define the kinetics of the ammonium nitrogen absorption from the sewage water on the clinoptilolite, each of the three glass flasks was filled with the $1 \mathrm{dm}^{3}$ solutions prepared previously. The first flask contained the solution with the ammonium nitrogen content $\left(\mathrm{C}_{\text {init }}=\right.$ $\left.=2.19 \mathrm{mg} \cdot \mathrm{eq} / \mathrm{dm}^{3}\right)$, the second flask had the model twocomponent solution with the ammonium ion content $\left(\mathrm{C}_{\mathrm{init}}=\right.$ $\left.=2.17 \mathrm{mg} \cdot \mathrm{eq} / \mathrm{dm}^{3}\right)$ and phosphates with the initial concentration $\left(C_{\text {init }}=0.207 \mathrm{mg} \cdot \mathrm{eq} / \mathrm{dm}^{3}\right)$. The third solution was the three-component system with the initial con-centration of the ammonium nitrogen $\left(\mathrm{C}_{\text {init }}=2.17 \mathrm{mg} \cdot \mathrm{eq} / \mathrm{dm}^{3}\right)$, phosphates $\left(C_{\text {init }}=0.213 \mathrm{mg} \cdot \mathrm{eq} / \mathrm{dm}^{3}\right)$ and albumin $\left(\mathrm{C}_{\text {init }}=0.077 \mathrm{mg} \cdot \mathrm{eq} / \mathrm{dm}^{3}\right)$. The $\mathrm{pH}$ of the three-component solution was 6.6. Note that concentrations of the polluting components in the model solutions corresponded to the content of the same pollutants in the real sewage water from the meat processing plants.

Equal portions of the sorbent $\sim 10 \mathrm{~g}$ were added to the solutions. The flasks were sealed, stirring was performed by using a mechanical stirrer, and samples were taken in certain intervals of the solution-adsorbent contact time. The experiments were carried out at $(293 \pm 0.5) \mathrm{K}$. The taken samples of the solution were analyzed for the content of the ammonium ions by using the photocolorimeter and the technique [9].

This sorbent was also tested for the kinetics of adsorbing by it the above-mentioned polluting components from the real sewage water with the content of the initial concentrations as follows: ammonium ions $\left(\mathrm{C}_{\text {init }}=\right.$ $\left.=1.73 \mathrm{mg} \cdot \mathrm{eq} / \mathrm{dm}^{3}\right)$, phosphates $\left(C_{\text {init }}=0.15 \mathrm{mg} \cdot \mathrm{eq} / \mathrm{dm}^{3}\right)$, and protein $\left(C_{\text {init }}=0.071 \mathrm{mg} \cdot \mathrm{eq} / \mathrm{dm}^{3}\right)$. The technique for carrying out the experiment and analysis of the ammonium ion content are similar to those in the model investigation. The $\mathrm{pH}$ of the sewage water was 7.68 .

\section{Results and Discussion}

A specific feature of zeolites is the fact that they may be used as adsorbents and as ion exchangers [10]. Otherwise, the sodium ions, which are capable of exchanging with the additionally charged cations from the solution, are counterions. The exchange reaction between the zeolite and $\mathrm{NH}_{4}{ }_{4}$ ion can be written as:

$$
\mathrm{R}-\mathrm{Na}+\mathrm{NH}_{4}^{+} \leftrightarrow \mathrm{R}-\mathrm{NH}_{4}+\mathrm{Na}^{+}
$$

where $\mathrm{R}$ are fixed ions which form a matrix of the ion exchanger and cannot pass into solution. The obtained relationships of $\mathrm{NH}_{4}^{+}$ion concentration in $\mathrm{C}_{\mathrm{NH} 4+}$ solution versus $\mathrm{NH}_{4}^{+}$concentration in a solid phase (zeolite exchange capacity) $a^{*}$ are plotted in Fig. 1 (curve 1), which shows that for a given interval of $\mathrm{C}_{\mathrm{NH} 4+}$ concentrations the relationship with slight deviations in the area of low $\mathrm{C}_{\mathrm{NH} 4+}$ concentrations $<0.5 \mathrm{mg} \cdot \mathrm{eq} / \mathrm{l}$ is linear and for a given constant temperature of $(293 \pm 0.5) \mathrm{K}$ it is an isotherm of an ion exchange sorption, that corresponds to the first linear section of the Langmuir isotherm, and this relationship is approximated by linear Henry equation (1) which for the investigated area $\left(\mathrm{mg} \cdot \mathrm{eq} / \mathrm{dm}^{3}\right)$ :

$$
0<\mathrm{CNH}_{4}^{+}<2 \text { has the form: } \quad a^{*}=0.271 \mathrm{C}_{\mathrm{NH} 4+}
$$

Curve 2 (Fig. 1) corresponds to the isotherm of the ammonium nitrogen sorption in the presence of the phosphates (normalized pollutant of the sewage water from meat processing plants). These values indicate the decrease 
of the zeolite exchange capacity due to its competition for the active centers of the adsorption.

With the presence of the third component (albumin, wich is a proteins substance) in the solution, there is observed a greater decrease of the zeolite sorption capability to the ammonium ions (curve 3 ). Thus, in the presence of the phosphates the equilibrium capacity decreases approximately by $30 \%$, then in the threecomponent system its decrease is about $70 \%$.

Substantiation of the kinetics of the ion exchange and its mathematical description are based on the sorption mechanism which allows to establish the process stage by limiting. The experimental investigations permitted to obtain the relationships of the change of the ammonium nitrogen concentration in the solution versus time $t$ (Fig. 2).

The analysis of the kinetic curve of the ammonium nitrogen adsorption (Fig. 2, curve 1) reveals dynamics of the ammonium ion content decrease in the solution during the given solution-sorbent contact time, with a great quantity of the ammonium cation decreasing in the first time interval (5 $\mathrm{min}$ ) and its content decreasing gradually in the following time intervals. During the 20 min solutionsorbent contact, the concentration of the ammonium nitrogen decreased in relation to the initial one approximately twice and reached the maximum permissible normal which is allowed for the discharge of the sewage water into common sewer nets (MAC of $\mathrm{NH}_{4}^{+}<1.1 \mathrm{mg} \cdot \mathrm{eq} / \mathrm{dm}^{3}$ ).

It is known [1] that the ion exchange mechanism consists of five stages:

1) Diffusion of $\mathrm{NH}_{4}{ }^{+}$ions from the solution to the exchanger surface.

2) Internal diffusion of $\mathrm{NH}_{4}{ }^{+}$ions in the sorbent grain.

3) Chemical substitution reaction for substituting of $\mathrm{NH}_{4}^{+}$for $\mathrm{Na}^{+}$counterion.

4) Internal diffusion of $\mathrm{Na}^{+}$counterion to the surface of the sorbent grain. solution.

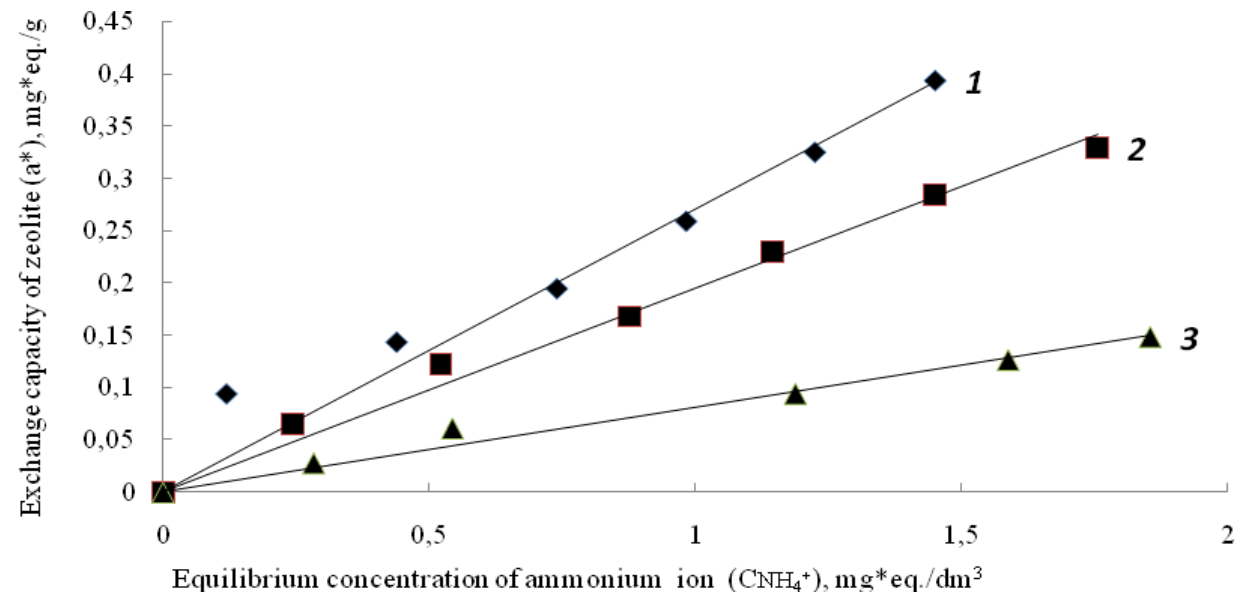

Fig. 1. Isotherms of ammonium nitrogen sorption on natural zeolite: isotherm of ammonium nitrogen sorption ( $)$; isotherm of ammonium nitrogen sorption at the presence of phosphates ( $\mathbf{a})$ and isotherm of ammonium nitrogen sorption at the presence of phosphates and albumin $(\boldsymbol{\Delta})$

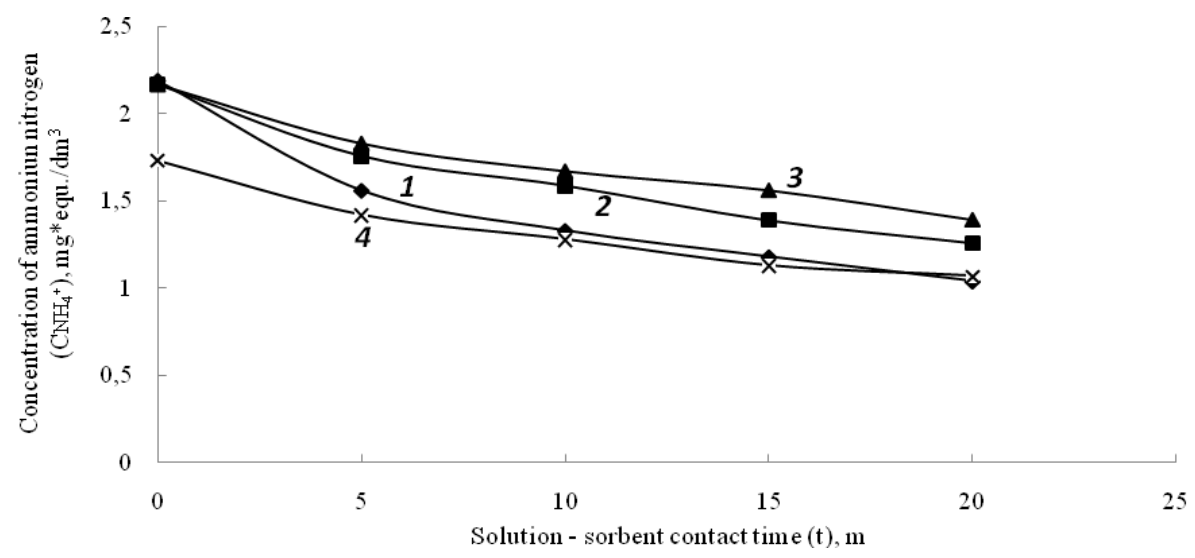

Fig. 2. Kinetics of ion exchange sorption of ammonium nitrogen: sorption of ammonium nitrogen ( $\bullet$ ); sorption of ammonium nitrogen at the presence of phosphates ( $\mathbf{m})$; sorption of ammonium nitrogen at the presence of phosphates and albumin $(\boldsymbol{\Delta})$ and sorptions of ammonium nitrogen from sewage water (X) 
The stage of the ion-exchange reaction (3) proceeds very quickly, therefore only diffusion processes may be limiting: external or internal diffusion. External-diffusion processes (stages 1 and 5) are determined by hydrodynamics. In case of intensive stirring, which was used in our experiments, the external-diffusion resistance is much lower than the internal-diffusion resistance, therefore the kinetics of the process is limited by stages 2 and 4 and is described by mathematical methods using the differential equations of the molecular diffusion in capillary-porous bodies [11]. Assuming that the adsorbent grains are ballshaped, the differential equation of the molecular diffusion has the form:

$$
\frac{\partial C_{a}}{\partial t}=D \cdot\left(\frac{\partial^{2} C_{a}}{\partial r^{2}}+\frac{2}{r} \frac{\partial C_{a}}{\partial t}\right)
$$

where $C_{a}$ is a volume concentration of $\mathrm{NH}_{4}{ }^{+}$ions inside the zeolite grain; $r$ is a variable grain radius; $t$ is time.

The intensive stirring of the solution and changing the process to the internal-diffusion one means that the concentrations of $\mathrm{NH}_{4}^{+}$in the solution and on the outer surface of the zeolite grains are equal, and the number $B i=\infty\left(B i=\frac{\beta R}{D^{*}}\right)$.

In Eq. (2) $C_{a}$ is a variable concentration of $\mathrm{NH}_{4}{ }^{+}$on the radius $\mathrm{r}$ of the zeolite grain $(0 \leq r \leq R ; R$ is grain radius). It is not the variable concentration that is defined experimentally, but its averaged value:

$$
\bar{C}_{a}=\frac{3}{R^{3}} \int_{0}^{R} r^{2} C_{a} d r
$$

The relation between $\mathrm{NH}_{4}{ }^{+}$concentration $\mathrm{C}_{1}$ in the solution and an averaged concentration $\bar{C}_{a}$ is defined from the material balance equation:

$$
V\left(C_{10}-C_{1}\right)=\frac{m}{\rho_{a d}} \bar{C}_{a}
$$

$$
\text { Note that } \frac{\bar{C}_{a}}{\rho_{a d}}=a^{*} ; C_{10} \text { is the initial concentration }
$$

of the solution; $m$ is the zeolite mass; $\rho_{a d}$ is the zeolite density; $V$ is the solution volume.

The problem includes additionally initial and boundary conditions and the condition of the symmetry of concentration distribution on the zeolite grain. Using nondimensional parameters: $\varphi=\frac{r}{R} ; F_{O}=\frac{D^{*} t}{R^{2}}-$ the Fourier number, the problem can be written as:

$$
\left\{\begin{array}{l}
\frac{\partial C_{a}}{\partial F_{0}}=\frac{\partial^{2} C_{a}}{\partial \varphi^{2}}+\frac{2}{\varphi} \frac{\partial C_{a}}{\partial \varphi} \\
\bar{C}_{a}=3 \int_{0}^{1} \varphi^{2} C_{a} d \varphi \\
\alpha\left(1-\frac{C_{1}}{C_{10}}\right)=\frac{\bar{C}_{a}}{C_{a \infty}} \\
\left(\frac{\partial C_{a}}{\partial \varphi}\right)_{\varphi=0}=0 \\
C_{a}(\varphi, F o=0)=0 ; C_{1}(F o=0)=C_{10} \\
C_{1}(\varphi \geq 1, \tau)=C_{1}
\end{array}\right.
$$

In the system (5):

$$
\alpha=\frac{V \rho_{a d} C_{10}}{m \bar{C}_{a \infty}}=\frac{V C_{10}}{m a_{\infty}^{*}} ; a_{\infty}^{*}=0.271 C_{10}
$$

The system solution (5) was performed by the operational method based on Laplace transform [13].

In the transforms the system has a zero root and a set of roots which are defined from the characteristic equation:

$$
\operatorname{tg} \mu=\frac{3 \mu}{3+\alpha \mu^{2}}
$$

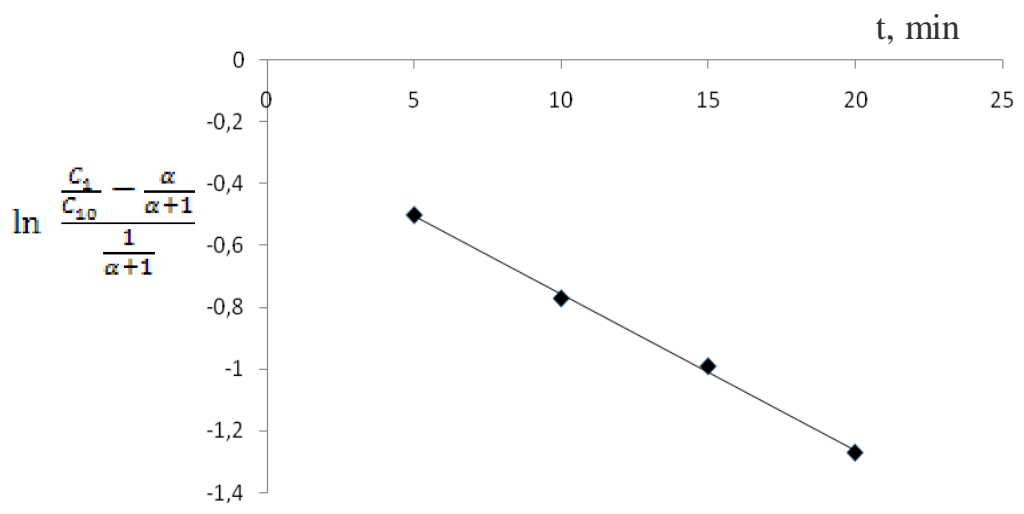

Fig. 3. Relation $\frac{\frac{C_{1}}{C_{10}}-\frac{a}{a+1}}{\frac{1}{a+1}}$ versus time $t$ 
Taking into consideration the zero root and the set of roots, the general solution of the system (5), represented through the changes of the concentration $C_{1}$ in a liquid phase of its change under conditions of the periodical process of the ion exchange sorption, can be written in the form:

$$
\frac{C_{1}}{C_{10}}=1-\frac{1}{1+\alpha}\left[1-\sum_{n=0}^{\infty} A_{n} \exp \left(-\mu_{n}^{2} F o\right]\right.
$$

where $A_{n}=\frac{6 \alpha(\alpha+1)}{9+9 \alpha+\alpha^{2} \mu_{n}^{2}}$ With great values of the root $\mu_{n}$ and great time $t$, the exponent value tends to zero, therefore the use of only the first root $\mu_{1}$ of the characteristic equation (regular operation area) is sufficient, and Eq. (7) can be reduced to:

$$
\frac{\frac{C_{1}}{C_{10}}-\frac{\alpha}{\alpha+1}}{\frac{1}{\alpha+1}}=A_{1} e^{-\mu_{1}^{2} F o}
$$

which in the semilogarithmic coordinate system $\ln \frac{\frac{C_{1}}{C_{10}}-\frac{\alpha}{\alpha+1}}{\frac{1}{\alpha+1}}=f(t)$ gives a straight line (Fig. 3).

A slope of the straight line $\gamma$ of the regular operation represents a value of:

$$
\operatorname{tg} \gamma=\mu_{1}^{2} \frac{D^{*}}{R^{2}}
$$

We define the internal counterdiffusion coefficient $D^{*}$ for the experiment conditions. The initial concentration for the ammonium ions is $C_{10}=39.5 \mathrm{mg} / \mathrm{dm}^{3}$. The equilibrium volume capacity of the zeolite (Fig. 1) $a_{0}^{*}$ is $10.7 \mathrm{mg} / \mathrm{g}_{\mathrm{ad}}$. The zeolite density $\rho_{a d}$ is $2150 \mathrm{~g} / \mathrm{dm}^{3}$, the grain porosity $\varepsilon_{p}$ is 0.3 [10]. The diameter of the zeolite fraction $d$ is $3.0 \mathrm{~mm}$.

Define the value of $\alpha: \quad \alpha=\frac{V \rho_{a d} C_{10}}{m \bar{C}_{a 0}}=0.369$

According to the relation (6), define the first root of the characteristic equation:

$$
\operatorname{tg} \mu_{1}=\frac{3 \mu_{1}}{3+0.369 \mu_{1}^{2}} ; \quad \quad \mu_{1}=10.0668
$$

Having defined $\operatorname{tg} \gamma=1.28 \cdot 10^{-3}$ (Fig. 3) from the relation (9), we find the internal counterdiffusion coefficient $D^{*}=2.84 \cdot 10^{-11} \mathrm{~m}^{2} / \mathrm{s}$. The final value of the concentration $C_{1}$ for the given periodical stirring conditions, with this value corresponding to the number of $F O=\infty$, and the conditions corresponding to equilibrium ones, from Eq. (7) will equal:

$$
\frac{C_{\text {leq. }}}{C_{10}}=\frac{\alpha}{1+\alpha}=0.269 ; \quad C_{\text {leq. }}=10.645 \mathrm{mg} / \mathrm{dm}^{3}
$$

The presence of other compounds in the solution decreases the value of the ammonum nitrogen sorption (curves 2 and 3, Fig. 2), that is explained by their competitiveness while they are moving in the adsorbent pores and by the competition for active centers.

Fig. 2 also shows the kinetics of the ammonium ion absorption from the real sewage water from the meat processing plant. The presented data indicate that $\mathrm{NH}_{4}{ }^{+}$ adsorption rate is adequate to curve 3 which corresponds to the model solution with the three-component system present.

\section{References}

[1] Zapolskyi A. (Ed.): Phizyko-Khimichni Osnovy Tekhnologii Ochyshchennya Stichnykh Vod. Libra, Kyiv 2000.

[2] Yakovenko Y., Khorunzhyi P., Khomunetska T. et al.: Mizhnarodna Naukovo-Prakt. Konf. "Suchasni Problemy Okhorony Dovkillya, Ratsional'noho Vykorastannya Vodnykh Resursiv ta Ochystky Pryrodnykh ta Stichnykh Vod", Myrhorod, April 23-27, 2007, 24.

[3] Zapol's'kyi A.: Vodopostachannya, Vodovidvedennya ta Yakist' vody. Vyshcha Shkola, Kyiv 2005.

[4] Merezhko A.: Gidrobiologicheskiy Zh., 1998, 34,66.

[5] Savchenko I. and Blagodatnyi V.: Okhrana Sredy ot Zagryazneniya Otkhodami Zhyvotnovodstva. Urozhai, Kyiv 1986.

[6] Datsenko I., Denysyuk O., Doloshytskyi S. et al.: Suchasni Problemy Hihiyeny Navkolyshniogo Seredovyshcha. L'viv 1997.

[7] Tkachenko S., Lariushkin Y. and Stepanov D.: Ekolohichnyi Visnyk, 2002, 5-6, 6.

[8] Dystanov U., Mykhailov A. and Konyukhova T.: Prirodnyie Sorbenty SSSR. Nedra, Moskwa 1990.

[9] Metodyka Photometrychnoho Vyznachennya Amoniy-ioniv z Reaktyvom Neslera v Stichnykh Vodakh. KND 211.1.4.030-95.

[10] Chielyshev N., Berenshtein B. and Volodin V.: Tseolity Novyi Tip Mineral'nogo Syria. Nedra, Moskwa 1987.

[11] Petrus R., Akselrud G., Gumnicki J. and Piantkowski W.: Wymiana Masy w Ukladzie Cialo Stale - Ciecz. Wyd. Politechniki Rzeszowskiej, Rzeszow 1998.

[12] Shyfrin S., Ivanova G., Mikulov B. and Fenofanov U.: Ochistka Stochnykh Vod Miasnoi i Molochnoi Promyshlenosti. Nedra, Moskwa 1981.

[13] Ditkin V. and Prudnikov A.: Operatsionnoye Ischeslenie. Vysshaya shkola, Moskwa 1975.

\section{СТАТИКА ТА КІНЕТИКА СОРБЦІї НІТРОГЕНУ АМОНІЙНОГО НА ПРИРОДНОМУ ЦЕОЛІТІ У ПЕРІОДИЧНИХ УМОВАХ}

Анотація. Експериментально досліджено статику та кінетику поглинання нітроген амонію на природному сорбенті у періодичних умовах. Розроблено математичну модель кінетики, визначено коефіиієнт дифузї протиіонів. Досліджено вплив фосфатних сполук $i$ білка на рівновагу та швидкість сорбиї амонійного-йону.

Ключові слова: нітроген амонійний, цееоіт, рівновага, математична модель, стічні води. 